Cronfa - Swansea University Open Access Repository

This is an author produced version of a paper published in:

International Ford Madox Ford Studies

Cronfa URL for this paper:

http://cronfa.swan.ac.uk/Record/cronfa23512

\title{
Paper:
}

Preece, J. (2015). Anglo-German Dilemmas in The Good Soldier, or: Europe on the Brink in 1913. International Ford Madox Ford Studies, 14(1), 223-240.

This item is brought to you by Swansea University. Any person downloading material is agreeing to abide by the terms of the repository licence. Copies of full text items may be used or reproduced in any format or medium, without prior permission for personal research or study, educational or non-commercial purposes only. The copyright for any work remains with the original author unless otherwise specified. The full-text must not be sold in any format or medium without the formal permission of the copyright holder.

Permission for multiple reproductions should be obtained from the original author.

Authors are personally responsible for adhering to copyright and publisher restrictions when uploading content to the repository. 


\section{ANGLO-GERMAN DILEMMAS IN THE GOOD SOLDIER, OR: EUROPE ON THE BRINK IN 1913}

\section{Julian Preece}

One would surely assume that a novel entitled The Good Soldier which was published in March 1915 would be set in the trenches of the western front. As the title was not Ford's first choice, that must surely have been his publishers' expectation if not his own. Taken metaphorically, as a comment on 'good soldiering' in war-time, the novel is anything but morale-boosting, of course, and contemporary reviewers were not slow to recognise its potentially unpatriotic import. The behaviour of the British officer class embodied by the eponymous good soldier Edward Ashburnham was decried at the time in one quarter as 'despicable'. ${ }^{1}$ Ford's depiction of loose sexual morals in the higher social echelons is still shocking. But Ford's preferred title 'the saddest story' would be overblown if it referred merely to an account of double adultery amidst a moneyed elite in pre-1914 Europe, albeit an account which narrates the suicides of both adulterers (the good soldier himself and the narrator's wife Florence), as well as the death of a second woman (Maisie Maidan) and the mental breakdown of a third (Nancy Rufford, usually known as 'the girl'), both would-be correspondents in a potential divorce case. The narrator John Dowell does let on at the outset that he is writing from the deceased Ashburnham's country estate, Branshaw Teleragh, but not that he has recently purchased this property, which makes him an American sitting inside the shell of former British grandeur. His New World naiveté in not noticing that he spends nine years chaperoning Florence to her trysts with his friend would have to be ascribed to saintly innocence (or holy folly) were it not up to a point meant to be taken metaphorically, even if he is having us on when he claims not to have known or is deliberately deluding himself. My argument proceeds from the premise that the war is the great unspoken presence in The Good Soldier, acknowledged not only in the title, which Ford insists was not his own idea, but also his use of the date 4 August, on which day in 1914, around six months before the novel was published, the United Kingdom declared war on Germany.

Dowell has great difficulty containing his story within the aesthetic parameters which he assigns himself. The elaborate narrative patterns which exceed his control can be argued, however, to articulate the political context which indeed led to Europe's 'saddest story'. Content challenges form in his repeated assertion of an imagined community with a listener, as he avers towards the beginning: 'So I shall just imagine myself for a fortnight or so at one side of the fireplace of a country cottage, with a sympathetic soul opposite me' (18). Wuthering Heights, which recounts a tale of more violent passions, makes use of just such a 'frame'. Boccaccio had proceeded in the same way in The Decameron, which was emulated in Germany by novella writers through the nineteenth century from Goethe in Conversations of German Emigrés (1795) to Theodor Storm in The Rider on the White 
Horse (Der Schimmelreiter, 1888). Ford may be recalling this classic ghost story set on the North German coast when he continues: 'And I shall go on talking, in a low voice while the sea sounds in the distance and overhead the great black flood of wind polishes the bright stars'. Nature may be threatening, mysterious, and unpredictable, but for Storm the cosmos retained its moral order. In 1935 Walter Benjamin wrote about the devastating effects of the First World War on the human capacity for experience, which he saw to be the basis for traditional story-telling:

A generation that had gone to school on a horse-drawn streetcar now stood under the open sky in a countryside in which nothing remained unchanged but the clouds, and beneath these clouds, in a field of force of destructive torrents and explosions, was the tiny, fragile human body. ${ }^{2}$

Ford could not know in late 1914 as he finished The Good Soldier the true horrors of trench warfare, but as a novelist he sensed enough. Orality was as passé as the epistolary novel. For this reason in The Good Soldier the narrative arrangement is merely a proposition. Dowell does not even attempt to simulate the traditional story-telling set-up, as there is no listener in the novel itself, as there is with Boccaccio, Brontë, and Storm.

Dowell covers up by trying a number of tactics. He ignores, pretends, dissembles, refuses to get to the point, and contradicts himself. As he cannot give us a full picture, he passes on redundant information, relaying the four characters' ages in two different formats on the first page, for instance, and professes an inability to describe. By the end, he is either deliriously confused or has veered into a dystopian fantasy because, if we follow his otherwise precise chronological markers, his narration post-dates the novel's publication. Given the events in the world outside, which had already hurtled into an abyss, it is not inappropriate that he should career ever further into an uncertain future.

If Dowell's own behaviour before he puts pen to paper can be connected to the causes of the war, then he sleepwalks to disaster, to borrow Christopher Clark's metaphor in the title of a recent book on the war's origins, one of a slew which has recently appeared to mark the centenary. ${ }^{3}$ The Sleepwalkers was also what the Austrian novelist Hermann Broch called his trilogy on the same theme published in 1931. The Anglo-German Ford Madox Ford either echoes or anticipates a number of key metaphors from ambitious Central European novels (by novelists such as Robert Musil, Jaroslav Hašek, Franz Kafka, Elias Canetti, Arthur Schnitzler and Thomas Mann as well as Broch), some of which are set retrospectively at this end point of European civilisation. Faux-naiveté was turned to devastating satirical effect by Hašek, whose 'good soldier Švejk' subverts the established order through the simple expedient of taking official pronouncements literally. Thus Švejk is arrested for expressing his patriotic joy as a loyal subject of the Emperor when he hears that war is declared; as an ethnic Czech the authorities assume that he must be faking his enthusiasm. Dowell is also both myopic and more or less incapable of emotional warmth and communication with a fellow human being, much like Peter Kien in Canetti's Auto-da-Fé (1935) or the aristocratic hero of Schnitzler's The Road into the Open (1911). That failure to connect or to take responsibility for words and deeds 
results in the novels by both Schnitzler and Canetti in moral catastrophe. What links both Florence Dowell and Edward Ashburnham with Mann's Hans Castorp in The Magic Mountain (1924), who spent seven years in a sanatorium in the Swiss Alps before being released to join the army in 1914 when the novel ends, is that none of them is really ill. Ford's use of illness, hypochondria and repressed eroticism as metaphors for feverish ethical short-sightedness also anticipates Mann's great novel of cultural cataclysm. Emptiness and lack are recurrent motifs in The Good Soldier. Dowell lives from rents that he earns from his New England properties, having no need to work and no inclination to practise a profession. Economically, he is a superfluous man. At least Ashburnham would have used up his fortune (which is also derived from rents) on the casinos and courtesans of Monte Carlo had he not been saved from his own appetites by the offices of his long-suffering wife. As he acknowledges towards the end, Dowell is a mirror image (perhaps an inverted image) of Ashburnham. The full initials of the serial seducer, gambler, drinker, 'sentimentalist' and upholder of the feudal ideal who lusts after his adopted daughter (who may even be his own daughter) are E.F.A., though we do not get to hear what the middle 'F' stands for. This is how Dowell recalls how he laid eyes on Ashburnham for the first time, observing him enter the dining room at the Hotel Excelsior in Nauheim:

His face hitherto had, in the wondrous English fashion, expressed nothing whatever. Nothing. There was in it neither joy nor despair; neither hope nor fear; neither boredom nor satisfaction. He seemed to perceive no soul in that crowded room; he might have been walking in a jungle (26).

Like Dowell himself, Ashburnham is another 'man without qualities', as Musil would entitle a much bigger multi-volume novel project on a similar theme which he sets in Vienna in the twelve months leading up to August 1914, and which also features brother-sister incest.

On 2 August 1914 Franz Kafka wrote in his diary: 'Germany has declared war on Russia. --Swimming lesson in the afternoon'. Some readers have seen in the entry his lack of interest in world affairs. But in what remained of the summer and through the autumn Kafka wrote his best known novel The Trial which, like The Good Soldier, is about a disruption to the settled patriarchal and bourgeois order. As Elisabeth Boa notes, it begins when a landlady fails to bring the novel's hero his breakfast in bed. ${ }^{4}$ On the same day, which is also his thirtieth birthday and thus traditionally associated with the assumption of adult responsibility, Josef K's advances to Fraulein Bürstner, his room neighbour in Frau Grubach's pension, who he wrongly thinks to himself is 'a little typist who will not resist me for long', are rebuffed. His first audience with the court is held in a working-class area of the city that he has not visited before (he arrives late because he was out the previous night with his friends). Edward's world is similarly under threat, which is expressed through challenges to his sexual and social supremacy. He was found guilty of importuning a nineteen-year-old nursemaid on a train. However, she not only fended him off, she pulled the communication cord and showed the strength of resolve to take him to court. Dowell reflects that: 'All her life, by her mother, by other 
girls, by schoolteachers, by the whole tradition of her class she had been warned against gentlemen.' (118) The law then backs her up and her assailant is punished. Is this not as fantastic as anything in Kafka? Dowell typically denies both the young woman agency and her assailant ill intent, blaming Edward's debacle on the maid's employer, the leader of the local anti-Tory Nonconformists who wants to ruin Edward as the local landowner.

A case can be made against Josef K. He is haughty, snobbish, arrogant, largely oblivious to the needs of others, and interested in furthering his own self advancement and satisfying his sexual needs, but his values are also those of the society which surrounds him, which is thus on trial along with the hero's own bad conscience. Similar charges could be made against Edward. His other escapades are no more edifying than the on-train assault. Out of his league with La Dolchita, he lays himself open to blackmail through his affair with Mrs Basil and relies on his wife to 'pimp' (the narrator's term) Maisie Maidan. ${ }^{5}$ As a scion of an ancient family and owner of a country estate, Captain Ashburnham DSO is a representative figure, associated closely with the British Empire. In addition to the suspicions that he was intimate with 'the girl' Nancy Rufford's mother, ${ }^{6}$ one of his last, apparently kindly and sentimental actions is to pay the legal fees of a young woman accused of infanticide. They amount to some £200. In earlier versions of the novel Ford referred to Edward's illegitimate children, but preferred ultimately to cast doubt over his paternity. The most horrifying element here may be that Dowell insists to the end that Edward's actions were always motivated by the noblest sentiments. ${ }^{7}$ Dowell's adopted discourse of noblesse oblige covers up 'the horror'.

Ford could not have known any of these German or Austrian novels because (except for Schnitzler's) they were published in the two decades after the war ended. My point is thus not that he borrowed from them, but that, working essentially with the same material, he identified some of the same pathological symptoms which he then turned into metaphors. ${ }^{8}$ He did, however, presumably know Goethe's Wilhelm Meister's Apprenticeship, a draft version of which (Wilhelm Meister's theatrical Mission) was published for the first time in $1911 .{ }^{9}$ Poems included in the novel were set to music over the nineteenth century by composers such as Beethoven, Schubert, Liszt, Schumann, and Wolf, becoming part of the classical repertoire. The most famous of these 'Kennst Du das Land?' (Do you know the land?) is sung in Italian by an enigmatic figure called Mignon, who is thirteen years old when she enters the novel. Mignon is associated with art, mystery, and sexuality. Her own sexual and even gender identity are indeterminate but at the end of the novel she dies of a broken heart when Wilhelm, who has acted as a surrogate father to her, announces that he will marry another woman. While Mignon's background is never entirely explained, she appears to be the victim of abuse and is revealed to be the product of an incestuous marriage between brother and sister. Characters resembling Mignon appeared in numerous works by German, French and English writers over the next one hundred years. Terence Cave lists texts in English by Thackeray, George Eliot, and Ford's contemporary and friend, Henry James. ${ }^{10}$ Nancy Rufford, whom Dowell refers to as 'the girl' or 'the 
poor girl', is surely another 'Mignonesque' figure. She has lived with Edward and Leonora since the age of thirteen. She comes from an abusive family. We are told that her father Major Rufford beat his wife and even once struck Nancy so hard 'that she had lain unconscious for three days' (101). While she has no association with art, on her last journey she travels through Italy, to where Mignon longed to return, cabling from Brindisi to say that she is well. The next that we hear from her she has suffered a breakdown which robs her of her mind on finding out about Edward's suicide. Nancy is the most allegorical character in the novel. Dowell professes to finding her 'queer' and 'very difficult to describe', eventually capitulating to what he regards as her contradictions:

She was tall and strikingly thin; she had a tortured mouth, agonised eyes, and a quite extraordinary sense of fun. You might put it that at times she was exceedingly grotesque and at times extraordinarily beautiful [...] She was just over twenty-one and at time she seemed as old as the hills, at times not much more than sixteen. (99)

Once she has gone mad, he calls her appearance 'a picture without meaning' (192). For Cave, Mignon is a threshold figure because she mediates between cultures and languages: hers is 'at its core $[\ldots]$ the reiterated story of vulnerability and severance, the story of an arrest at the threshold', all of which could apply to Nancy. ${ }^{11}$ Ford deploys her as an unacknowledged intruder from the German tradition which like the tradition she intrudes upon is in the process of going to the bad.

Whereas the recognition or 'anagnorisis' in Wilhelm Meister contained tragedy (Mignon's incestuous origins) and preceded her demise, here it is horrific: her own father became infatuated with her before blowing his brains out. Dowell senses the true import of the novel at the beginning of one of his early paragraphs with a sentence which readers have sometimes found a touch melodramatic. Reflecting on the meaning of his story, he compares it to the greatest event in ancient history which sealed the end of an epoch and the destruction of a civilisation: 'Some one has said that the death of a mouse from cancer is the whole sack of Rome by the Goths, and I swear to you that the breakup of our little four-square coterie was such another unthinkable event' (12). Ford is aware that the circumstances of this breakup express however indirectly some of the causes of the First World War.

A more tangible clue about Ford's intentions is contained in the date --- 4 August --- which, by a set of coincidences which even the studiedly unobservant Dowell finds remarkable, is the day on which, by his own lights at least, everything of note occurs in his wife Florence's brief life. It was her birthday; on 4 August 1899 when she turned twenty-five she set out on a world tour with 'her kindly uncle' (who may also be her father) and 'a young man called Jimmy', who certainly became her lover (65). Exactly one year later, she agreed to marry Dowell and eloped with him one year after that in 1901. On her thirtieth birthday in 1904 that Maisie Maidan suddenly died (for which, according to Leonora Ashburnham, Florence was co-responsible) and that the Ashburnhams and the Dowells made the fateful excursion to the Castle at M. It is at this Prussian location which was the site of the original 'protest' setting in motion the Reformation that Florence insults Leonora's Irish Catholicism and flaunts her liaison with Edward, Leonora's husband. On 4 August in 1913, either because she realises 
that her husband has heard that she was Jimmy's lover before they got married, as Dowell at first wants us to believe, or because she has overheard Edward express his love for Nancy, Florence takes her own life. Between 4 August 1904 and 4 August 1913 Dowell claims that there are nine years of 'nothing'. Florence thus takes a wrong turn at the threshold age of thirty in 1904 which ensures her failure to arrive at the next threshold age of forty in 1914 (Ford himself turned forty in 1913). In German modernist literature, failure to pass these threshold ages and to settle down into adulthood, secure in one's identity and integrated into a social environment, is a central trope. ${ }^{12}$

4 August 1914 was the day that Britain declared war on Germany, after Germany had failed to give assurances that it would respect the neutrality of Belgium as German troops mobilised to invade France. Austria-Hungary had declared war on Serbia a week earlier (28 July) as a consequence of the assassination of the Archduke Franz Ferdinand by a Bosnian Serb nationalist a month before that on 28 June. Serbia was allied to Russia which was allied to France which was allied to Britain. Germany declared war on Russia on 1 August (as Kafka noted in his diary the following day). For Ford's British readers 4 August 1914 marks the beginning of what came to be called the First World War, which is commemorated on different days across the Continent, as is, more bizarrely, its end. In the book on Germany that Ford wrote immediately after finishing The Good Soldier, he gives the impression that all hostilities between the various powers began precisely on 4 August, which then assumes greater symbolic significance. Explaining how, in his interpretation of events, German public opinion was manipulated against her future enemies, Ford writes:

the great bulk of the population of Germany seriously imagined before August $4^{\text {th }}, 1914$, that the French nation was so enfeebled as to be unable to offer any armed resistance to the legions of William II, the English so sunk in sloth, decadence, and the love of comfort as to be incapable of armed resistance or the power of commercial organisation in war time; and the Russian Empire a horde of negligible and impoverished barbarians. ${ }^{13}$

According to Max Saunders, working from manuscripts of the novel, Ford had already ascribed this pivotal function to the month of August if not to 4 August before war was declared. In Return to Yesterday, which ends with the assassination of the Archduke Franz Ferdinand, C.F.G. Masterman, predicted the outbreak of war one full year before it happened. As he and Ford holidayed on the Rhine, Ford recalls him announcing on 2 August 1913: 'By this date next year we shall be at war with Germany,' his reason being that Germany would be bankrupt by the following summer. As Ford reminds his readers, Masterman, was just 'two days out'. ${ }^{14}$ For Ford, 14 August 1914 is thus the key date.

The relationships between the major characters and their satellites in The Good Soldier are not wholly dissimilar to these tangled military alliances. Both engender unintended outcomes. In the novel there are two reasons for the significance of 4 August 1904 (Maisie Maidan's sudden death and the visit to the Castle at M.) Similarly, there are two explanations for Florence's suicide on 4 August 1913: either she killed herself because she realises that her husband has been told that she was not a 
virgin when they married or she has overheard Edward's advances to 'the girl' and fears her own affair with him is over. The causes of 4 August 1914 are being debated to this day. The entanglements and deceptions of the Ashburnhams and the Dowells do not directly reflect or represent the relations between states in the pre-1914 era. The novel's style is oblique and metonymic rather than allegorical. But behind the facade of good manners (Edward and Leonora only talk to each other when others are present), this quartet of 'quite good people' (12) is morally corrupt to a degree which beggars belief. That was certainly true of Great Power Europe too.

There are a series of binary oppositions in The Good Soldier which set individuals against each other in ways which do mirror the mechanisms of enmity between states. Dowell divides the characters into mutually uncomprehending camps: British and American, Anglo-Saxon and Continental European, Protestant and Catholic, English and Irish, subaltern and colonial. The narrative gains much of its power from Dowell's misapprehension of gestures and motives as he assigns people to their faith, class, political allegiance (for Americans: Democrat or Republican; or which side their family supported in the War of Independence), country or culture, while not naming the difference which drives the whole story: his own homosexuality. The Great War pitched most of these camps against each other, ending the leisured cosmopolitan world inhabited by the two married couples at the centre of the novel. All four principal characters have multiple affiliations. The Ashburnham marriage captures emblematically an idea of the British Empire as an unworkable sham. Both spouses are from military families, Edward is a Protestant Englishman and Leonora, née Powys an Irish Catholic. Rob Doggett has recently written that Leonora is the unknowable 'Irish other', but for this 'eminently perplexed narrator', as he calls Dowell, I would argue that all such 'others' are equally unknowable, which is why Dowell is such an inveterate 'otherer' in the first place. ${ }^{15}$ If there is hope (to paraphrase George Orwell) it lies with the subalterns: the Irish Catholic Leonora temporarily saves her husband by whisking him away from European fleshpots to colonial Burma and taking over the management of Branshaw Teleragh and his finances. According to Dowell, she wants her husband back for the sake of her religion and the integrity of a vanished order. Like the Dowells, the Ashburnhams have no children. Once Edward is dead, however, Leonora immediately becomes pregnant on remarrying. One index of a novel's historical optimism is its ratio of births to deaths. In the German and Austrian list that I have enumerated, babies are few and far between. Only Irish Catholics are fertile in The Good Soldier.

The other paper marriage is between a couple of wealthy New Englanders, the narrator John Dowell and Florence, née Hurlbird, who is descended from the original owners of Branshaw Teleragh. While Dowell introduces himself as no less English in origin than his wife ('the first Dowell [...] left Farnham in Surrey in company of William Penn' (12), making him an aristocrat among settlers) and he succeeds, where she fails, by ending up as owner and occupier of her ancestors' country seat, there is another ingredient to his identity which he is quieter about and which is not 
usually accorded the prominence it surely deserves by critics. Dowell is also of German stock. He reveals on the trip to the Castle at $\mathrm{M}$. that he speaks the language better than his wife, though without being able to rid himself of 'the accent of the Pennsylvania Duitsch of my childhood' (39). This 'Duitsch' is still spoken, but today, as in the latter part of the nineteenth century when Dowell grew up, only by members of the language community. Dowell is as coy about his German roots as he is about his sexuality. While he and Florence are both American, through their ancestors their union represents an Anglo-German alliance, which makes the novel into a kind of round dance of the AngloIrish and the Anglo-Germans.

Branshaw Teleragh is the novel's point of origin (as Florence's ancestors owned it before they emigrated to the New World) and its point of return. The Good Soldier nevertheless begins properly in the cosmopolitan German Spa town of Nauheim. Here Dowell is alienated by his surroundings. Before the Ashburnhams' entrance he describes his detachment as he stands on the steps of the Englischer Hof or 'English Court': 'Natty, precise, well-brushed, conscious of being rather small amongst the long English, the lank Americans, the rotund Germans, and the obese Russian Jewesses' (p.25). By birth or heritage, Dowell is English, American, and German but he does not fit in amongst any of them any more than he does amongst the fat Russian Jewish women. Petra Rau sees the hotel as a counterpoint to Branshaw Teleragh:

The novel's sexual and epistemological crises, however, are also constructed as crises of Englishness, denoted through the loci of its melodrama, the Hotel Englischer Hof and the English countryhouse, both of which fail to contain transgressive desire as if it were some heinous German bacillus that has infected the social fabric. ${ }^{16}$

Except that the English are also Irish, American and German. The name of the establishment indicates a kind of German Anglophilia and stands in the novel as a piece of England on foreign soil. The hotel in Nauheim which bore this name in 1913 is now called the Bayrischer Hof or 'Bavarian Court'.

There are four further episodes in Germany involving German figures either living or dead which I would now like to interpret in the light of the calamity of 4 August 1914. These are: the brief account of Edward's polo match against a German team (29), which shows the archetypal military Englishman and British imperialist triumphant in mock battle with the future foe: the visit to M. on 4 August 1904; the annual dinner at Nauheim for the Grandduke of Nassau Schwerin hosted jointly by the Dowells and the Ashburnhams; and Florence's death from an overdose of amil nytrate on 4 August 1913. The reader is told that the Castle at M. is where Luther, Zwingli, Martin Bucer, and the 'trigamist' Ludwig the Courageous signed the 'protest' which, as Florence triumphantly informs the assembled company, 'is why we were all called Protestants' (39). Her announcement has the intended effect of alienating Leonora, as Florence calculated that it would, but Maisie Maidan, Florence's other rival who dies that very day, is also Irish. If Leonora is thus marginalised, the Anglo-American trio of Protestants are allied with their German or Prussian confreres. Ford blamed the war not on Germany but on Prussia, tracing the war's origins to the Reformation, which he interpreted to have been a 
Prussian affair, arguing further that 'The religious struggle $[\ldots]$ that began in Germany in the days of Holbein has impoverished Germany from that day to day this, and is, I think I can prove, one other direct cause of the war at whose hands to-day we are all suffering $\cdot{ }^{17} \mathrm{M}$. is not only identified with Luther's protest as, according to Dowell, it 'has the disadvantage of being in Prussia; and it is always disagreeable to go into that country' (36). Dowell appears to share Ford's antipathy to the dominant force in the German Reich while retaining a positive attitude towards other non-Prussian (and Catholic) regions of Germany. His father was born in Münster in the northern part of the Catholic Rhineland, which became Prussian at the Congress of Vienna in 1815. Ford himself ascribes all that is good and likeable about Germany to the southern parts of the country, while blaming Prussia for everything that set the Reich on a collision course with Britain. As political or cultural history, this is more or less nonsense, though became an influential view during the Second World War, at the end of which Prussia was officially dissolved by the Allies. On Ford's part, it is a strategy for dealing with his split loyalties. In the metaphorical scheme of The Good Soldier it collapses the 'German' part of any binary opposition, since 'German' itself divides into 'good' and 'bad'.

At Nauheim the two couples find themselves playing the role of impromptu diplomats inviting the Grandduke 'and a good many of his suite and any members of the diplomatic bodies that might be there' to a dinner, which 'became a sort of closing function for the season, at any rate as far as we were concerned' (33). The Grand Duke reminds Dowell of the British King, who like Ford had a German father and English mother, 'the late Edward VII' (34), in his pleasantness and affability. These are attributes which were never attached to the Grand Duke's nephew the Emperor Wilhelm II about whom we are told he would occasionally talk. Once again there is a split, this time between the good Germany of the old nobility which is anglicised in its manners and the bad Germany of the Prussian Hohenzollerns, which is in the ascendancy. Another Grand Duke along with a chief of police and a hotelier officiate over Florence's corpse. Ford conveys a sense that representatives of three estates are present. painting a tableau vivant of the German state: an ineffectual but charming leader, an aggressive policeman, and a representative of commerce who is reminiscent of a clergyman with poor personal hygiene or worse. Dowell remembers only their faces, which 'seemed to bob into my consciousness, like floating globes':

At times one head would be there alone, at another the spiked helmet of the official would be close to the healthy baldness of the prince; then M. Schontz's oiled locks would push in between the two. The sovereign's soft, exquisitely trained voice would say, 'Ja, ja, ja!' each word dropping out like so many soft pellets of suet; the subdued rasp of the official would come: 'Zum Befehl Durchlaucht,' like five revolver shots; the voice of M. Schontz would go on and on under its breath like that of an unclean priest reciting from his breviary in the corner of a railway-carriage. (p.88)

Nauheim is beyond the border of Prussia, which situates it in the 'better' southern Germany whose inhabitants have a natural inclination, according to Ford, 'towards the French language and French forms of culture'. ${ }^{18}$ This must be why the hotelier is a 'monsieur' rather than a 'Herr'. Comparing him with a sinful priest aligns him with a waning Catholicism which will not be strong enough to mediate 
between other two forces let alone support the Grand Duke against the military mannered chief of police. Though the 'Pickelhaube' was worn throughout Germany by the late nineteenth century, the police chief's signature phrase ('At your command, your highness') align him with the Prussianised Germany that Ford reviled and blamed for the war.

This is the last reference to Germany or Germans. There remains the German-American Dowell himself, who at the close occupies the grand but empty house of England with only his terminally damaged Mignon for company. Between them they represent two cultures in ruins.

\footnotetext{
${ }^{1}$ J.K. Prothero, quoted by Max Saunders, in 'Introduction', Ford Madox Ford, The Good Soldier (Oxford: Oxford University Press, 2012), Oxford World Classics, new ed., vii-xliii, here xxvi. All references are to this edition; henceforth I give page numbers in brackets after quotations. An anonymous reviewer affected disbelief in the journal Outlook: 'Captain Ashburnham [...] is described to us as a typical specimen of the best kind of Englishman, an officer and a gentleman, a good landlord, a staunch friend. It is therefore inconceivable that he should have behaved as [...] Mr Hueffer tells us he did behave', in Ford Madox Ford, The Good Soldier (London/New York: Norton, 1995), ed. Martin Stannard, pp.226-27, here p.226. On the choice of title and the shocked reactions to the novel, see also Max Saunders, Ford Madox Ford: A Dual Life (Oxford: Oxford University Press, 2012), pp.417-19. First published 1996.

${ }^{2}$ Walter Benjamin, 'The Story Teller', Illuminations, tr. Harry Zohn

${ }^{3}$ Christopher Clark, The Sleepwalkers. How Europe went to war in 1914 (Harmondsworth: Penguin, 2013).

4 'The cook employed by Frau Grubach his landlady, who brought him his breakfast every day at eight o'clock, did not come today'. Franz Kafka, Der Process (1914/15, pub. 1924, The Trial) Elizabeth Boa,
}

${ }^{5}$ One can also argue that Dowell pimps his wife Florence to Edward in a similar fashion. See Rose de Angelis, 'Narrative Triangulations: Truth, Identity, and Desire in Ford Madox Ford's The Good Soldier', English Studies 88:4 (2007), pp.42546, esp. p.434.

${ }^{6}$ Saunders, A Dual Life, pp.421-23.

${ }^{7}$ Saunders recognises the contradiction in the novelist's own allegiances: 'Ford's nostalgic admiration for the paternal landowner is unmistakeable, even as he reminds us that the droit de seigneur involves not only being a father to your tenants, but fathering their children', ibid., p.427.

${ }^{8}$ Saunders acknowledges that the novel 'comes out of many of the same tensions and forces which produced the war', ibid., p.431. 
${ }^{9}$ Wilhelm Meisters theatralische Sendung. Nach der Schulthess'schen Abschrift zum ersten Male herausgegeben von Harry Maync (Berlin / Stuttgart: 1911). A central chapter in When Blood is their Argument: An Analysis of Prussian Culture (London: Hodder and Stoughton, 1915) is on the subject of 'Goethe as Superman', pp.270-90.

${ }^{10}$ Terence Cave, Mignon's Afterlives: Crossing Cultures from Goethe to the Twenty-First Century (Oxford: Oxford University Press, 2011).

${ }^{11}$ Ibid., p.265.

${ }^{12}$ See Theodor Ziolkowski,

${ }^{13}$ When Blood is their Argument, p.213.

${ }^{14}$ Ford Madox Ford, Return to Yesterday, edited and with an introduction by Bill Hutchings (Manchester: Carcanet, 1999), p.315. First published 1931.

15 Rob Doggett, "'Those were Troublesome Times in Ireland, I understand": Ireland, the Limits of knowledge, and Ford Madox Ford's The Good Soldier', Modern Fiction Studies 53:4 (2007), pp.697-721, p.698. He continues that 'the novel explores a set of issues that are fundamentally intertwined with the Irish Question: the viability of the British Empire; the decay of the old aristocracy; and the decline, at both the colonial periphery and the imperial center, of a political, economic, and cultural system based on land ownership', p.699.

${ }^{16}$ Petra Rau, English Modernism, National Identity and the Germans, 1890-1950 (Farnham, Surrey: Ashgate, 2009), p.108. See esp. her chapter on the use Ford makes of Bad Nauheim: 'Ford's "Tricky German Fashion". Medical Modernity and Anglo-Saxon Pathology', pp.89-112.

${ }^{17}$ When Blood is their Argument, p.8.

${ }^{18}$ Ibid., p. 271. 